\title{
Antiangiogenic VEGF165b Expression in Human Breast MCF- 7 and MCF-10A Cells Exposed to Reverse Transcriptase and Protease Inhibitors
}

\author{
Expresión de VEGF165b Antiangiogénico en Células MCF-7 y MCF-10A de \\ Mama Humana Expuesto a Inhibidores de la Transcriptasa Inversa y la Proteasa
}

Adefolaju Gbenga Anthony ${ }^{1}$; Scholtz Kathrine Elizabeth ${ }^{1} \&$ Hosie Margot Jill ${ }^{2,3}$

\begin{abstract}
ADEFOLAJU, G.A.; SCHOLTZ, K. E. \& HOSIE, M. J. Antiangiogenic VEGF165b expression in human breast MCF-7 and MCF10A cells exposed to reverse transcriptase and protease inhibitors. Int. J. Morphol. 35(1):148-156, 2017.

SUMMARY: The combined antiretroviral therapy (cART), a multidrug combination regimen, usually consisting Nucleoside Reverse Transcriptase Inhibitors, non- Nucleoside Reverse Transcriptase Inhibitors and Protease Inhibitors has altered the morbidity pattern affecting HIV-infected individuals to include non-AIDS-defining malignancies (nADMs). The speculation is rife; does cART induce or promote the progression of nADMs such as breast cancer? This study was therefore designed to investigate of the effects of some antiretroviral drugs (at clinically relevant concentrations) on the expression of anti-angiogenic gene; VEGF165b in two human breast cell lines; MCF-7 and MCF-10A by Real Time qPCR and immuno-fluorescence. All of the antiretroviral drugs and combinations tested produced patterns of slight up or downregulation of VEGF165b mRNA expression but the alterations did not attain statistical significance. They also did not alter VEGF165bprotein localisation in both cell lines. The findings reported here suggest that antiretroviral drugs probably do not influence the angiogenic pathway in the development of breast cancer in patients under the combined antiretroviral regimen.
\end{abstract}

KEY WORDS: Reverse Transcriptase Inhibitors; Protease Inhibitors; VEGF165b; Breast cancer; MCF-7; MCF-10A.

INTRODUCTION

The combined antiretroviral therapy (cART), a multidrug combination regimen, has increased the life expectancy of HIV-infected individuals while the incidence of AIDS-defining malignancies and opportunistic infections has dramatically decreased (Nachega et al., 2004; Sikora et al., 2010). cART is currently the treatment of choice in South Africa; the nation with the highest number of HIV infected patients (Maqutu et al., 2011). The original development of the antiretroviral drugs was focused primarily on reducing mortality (Blas-García et al., 2010). Focus has since shifted from the primary considerations to the long-term unwanted effects induced by this treatment regimen (Blas-García $e t$ $a l$.). It has not been clearly shown whether or not antiretroviral compounds are oncogenic (Powles et al., 2009). Torres et al. (2007) suggested that the clinical use of NRTI drug pairs may "lead to additive or synergistic effects compounding long-term risk for cancer gene mutations and potential carcinogenesis".
The overall effect of cART on the risk for Non AIDS defining malignancies (NADM), including breast cancer has not been clearly established. An HIV/AIDS cohort conducted in England (Powles et al.,) showed that a rise in the risk for Non-AIDS defining Malignancies significantly accompanied cART treatment. Engels et al. (2008) found that non-AIDS defining cancers comprise $58 \%$ of all cancer deaths postHAART (1996-2002) in comparison to $31.4 \%$ in the preHAART era (1991-1995). Whilst other risk factors may play a part, the suggestion that antiretroviral drugs may influence cancer development and progression is currently explored (Adefolaju et al., 2014; Silverberg \& Abrams, 2007).

Angiogenesis, the formation of new blood vessels from pre-existing vasculature is required for cancer growth and development (Bates et al., 2002). It is the growth and multiplication of a system of blood vessels that invades tumors, supplying nutrients and oxygen serving to remove

\footnotetext{
${ }^{1}$ Department of Preclinical Sciences, School of Health Care Sciences, University of Limpopo Private Bag x1106, Sovenga 0727, South Africa.

${ }^{2}$ School of Anatomical Sciences, University of the Witwatersrand, Medical School, 7 York Road, Parktown 2193, South Africa.

${ }^{3}$ Newcastle University Medicine, Johor, Malaysia.
} 
wastes (Bates et al.) Tumor angiogenesis begins when cancer cells release factors that convey signals to neighbouring normal host cells and tissue. This process triggers specific genes in the host cells that consequently synthesize proteins that promote the development of new blood vessels (Bates et al.). The creation of new blood vessels is a complicated process that involves more than 50 co-dependent growth factors, cytokines, enzymes and receptors (Carmeliet, 2000), and several of them are reported to be from the vascular endothelial growth factor A (VEGFA), angiopoietin and ephrin families. The VEGFA family perform important functions in vasculogenesis, angiogenesis and lymphangiogenesis. There are five members of the human VEGF family: VEGF (or VEGF-A), VEGF-B, VEGF-C, VEGF-D, and placental growth factor (PlGF) (Achen et al., 1998; Ferrara, 2004; Hoeben et al., 2004; Joukov et al., 1996; Olofsson et al., 1996). Alternative gene splicing of the respective human VEGF premRNAs produces several isoforms of each gene. VEGFA signalling denotes a complex but crucial rate-limiting phase in angiogenesis and as a result is the subject of concentrated research (Nowak et al., 2008). The VEGFA gene consists of 8 exons set apart by 7 introns and spans 14 kilo bases (Houck et al., 1991). VEGF pre-mRNA is differently spliced to generate mRNAs that encode about 12 isoforms that have been researched widely, some possessing pro-angiogenic and others possessing anti-angiogenic properties (Houck et al.; Nowak et al.; Perrin et al., 2005). One of the isoforms is VEGF165, with 165 amino acids in its complete structure. However, recent evidence indicates that two families of VEGF proteins are formed by alternative splice-acceptor-site assortment in the $3 \phi$ untranslated region (UTR) within the terminal exon 8 to give 2 different $\mathrm{C}$-terminal sequences that differ in only 6 amino acids (Bates et al.; Qiu et al., 2009). Proximal spliceacceptor-site selection in exon 8 results in classic proangiogenic VEGFxxx isoforms that contain the exon 8a sequence, whereas distal splice-acceptor-site selection produces antiangiogenic VEGFxxxb isoforms that contain the exon $8 \mathrm{~b}$ sequence (with $\mathrm{xxx}$ denoting the number of amino acids) (Qiu et al.). The proangiogenic isoforms encode a terminal 6amino acid sequence of Cys-Asp-Lys-Pro-Arg-Arg, while the antiangiogenic isoforms encode Ser-Leu-Thr-Arg-Lys-Asp. The most widely studied VEGFxxxb isoform is VEGF165b, but other isoforms have also been identified at both the mRNA and protein levels (Qiu et al.). There is an extensive expression of the VEGF165b transcript and protein in majority of normal human tissues and in nonangiogenic tissues (Qiu et al.). VEGF165b has dimerization and receptor-binding regions, therefore, it functions as a competitive inhibitor of VEGF165; such that it binds to the receptor but fails to trigger the complete tyrosine phosphorylation of VEGF Receptor-2 and the subsequent signaling provoked by VEGF165 (Woolard et al., 2004). VEGF165b therefore is said to be an intrinsic antiangiogenic agent produced by alternate splicing (Woolard et al.). Recent reports indicate that the control of alternative splicing by growth and splicing factors represents an important step in influencing the comparative expression of proangiogenic as against antiangiogenic VEGF isoforms (Nowak et al.; Qiu et al.; Rennel et al., 2009). Since the amino acid configuration of antiangiogenic VEGF165b is $95 \%$ to $96 \%$ similar to that of VEGF165 (Qiu et al.; Woolard et al.), the majority of past studies that have investigated VEGF expression could not differentiate between these proangiogenic and antiangiogenic VEGF isoforms. It is noted that the majority of these studies were conducted before the discovery of antiangiogenic VEGF isoforms or used in situ hybridization riboprobes, antibodies, and ELISAs that detect both VEGF165 and VEGF165b isoforms (Manetti et al., 2011). The aim of the present study therefore, was to investigate whether the expression of the anti-angiogenic VEGF splice variant; VEGF165b could be altered in human breast cell lines exposed to different classes of antiretroviral drugs, individually and in combination. We hypothesised that, for antiretroviral drugs to promote tumor angiogenesis, VEGFA165b mRNA might be down-regulated.

\section{MATERIAL AND METHOD}

Cells. Human breast carcinoma MCF-7 cells (American Type Culture Collection Rockville, MD, USA) were cultured in DMEM medium (Gibco BRL, Gaithersburg, MD, USA) containing $10 \%$ Fetal Bovine Serum (Gibco, USA).

Immortalized human breast epithelial cells, MCF-10A (American Type Culture Collection Rockville, MD, USA) were cultured in Mammary Epithelium Growth Medium (MEGM) (Lonza, Walkersville, MD USA) containing human recombinant epidermal growth factor, hydrocortisone, insulin and bovine pituitary extract (Lonza, MD USA).

Cells were cultivated as a stationary monolayer in plastic tissue-culture dishes (Nunclon, Denmark) and were incubated at $37^{\circ} \mathrm{C}$ in a $5 \% \mathrm{CO}_{2}$ humidified environment. The cells were incubated with the drugs individually and in combination at the indicated physiologically relevant concentrations for 96 hours.

Drugs and Treatment. Drugs were administered at concentrations which reflect their steady-state plasma peak concentration. FTC and TDF were dissolved in distilled water, while EFV, LPV and RTV were dissolved in methanol. The cells were incubated with the drugs individually and in combination at the indicated concentrations (Table I) for 96 hours. Normal and vehicle control groups were exposed to growth medium and vehicle respectively (Groups 1 and 2). 
Table I Shows the treatment groups and drug concentrations administered for each cell line.

\begin{tabular}{ll}
\hline GROUP & TREATMENT \\
\hline $\mathbf{1}$ & Growth Medium \\
$\mathbf{2}$ & $0.01 \%$ Methanol \\
$\mathbf{3}$ & $0.3 \mu \mathrm{g} / \mathrm{ml} \mathrm{TDF}$ \\
$\mathbf{4}$ & $1.8 \mu \mathrm{g} / \mathrm{ml} \mathrm{FTC}$ \\
$\mathbf{5}$ & $4.07 \mu \mathrm{g} / \mathrm{ml} \mathrm{EFV}$ \\
$\mathbf{6}$ & TDF+FTC+EFV (ATRIPLA) \\
$\mathbf{7}$ & $9.8 \mu \mathrm{g} / \mathrm{ml} \mathrm{LPV}$ \\
$\mathbf{8}$ & $0.6 \mu \mathrm{g} / \mathrm{ml}$ RTV \\
$\mathbf{9}$ & LPV $/ \mathrm{r}(\mathrm{KALETRA})$ \\
$\mathbf{1 0}$ & TDF+FTC+LPV/r \\
\hline
\end{tabular}

The cells were exposed to $0.3 \mathrm{mg} / \mathrm{ml} \mathrm{TDF} ; 1.8 \mathrm{mg} / \mathrm{ml}$ FTC; $4.07 \mathrm{mg} / \mathrm{ml} \mathrm{EFV} \mathrm{individually} \mathrm{(Groups} \mathrm{3-5)} \mathrm{and} \mathrm{in}$ combination (Group 6) as recommended by the South African antiretroviral treatment guideline and as in ATRIPLA®. Cells were also exposed to $9.8 \mathrm{mg} / \mathrm{ml} \mathrm{LPV} \mathrm{(Group} \mathrm{7)} \mathrm{and} \mathrm{LPV/r}$ (Kaletra $\left.{ }^{\circledR}\right)$. Even though the absolute bioavailability of Ritonavir had not been determined in humans at the time of this study (Drug information, NORVIR® Abbott laboratories), across studies, administration of Kaletra ${ }^{\circledR} 400 / 100$ mg daily yields mean steady-state lopinavir plasma concentrations 15 to 20 times higher than those of ritonavir in HIV-1 patients (Drug information, KALETRA® Abbott laboratories, 2013). Therefore a $9.8 \mathrm{mg} / \mathrm{ml} \mathrm{LPV:} 0.6 \mathrm{mg} / \mathrm{ml} \mathrm{RTV} \mathrm{ratio} \mathrm{of} \mathrm{lopinavir}$ to ritonavir was used. In group 8 , cells received $0.6 \mathrm{mg} / \mathrm{ml}$ RTV only. Another group of cells (Group 10) received a combination of TDF, FTC and LPV/r; recommended as a 2nd line regimen in the South African antiretroviral treatment guideline.

Antibodies, Kits and reagents: Primary antibody- polyclonal rabbit anti-human VEGF165b and secondary antibody- Goat anti-rabbit Rhodamine conjugated were purchased from ABCAM (Cambridge, UK). The GeneJET RNA Purification kit, DNase I, RNase-free kit and O'GeneRuler Low Range DNA Ladder were purchased from Thermo Scientific (Pittsburgh PA. USA). High Capacity cDNA Reverse Transcription Kit and Power SYBR ${ }^{\circledR}$ Green PCR Master mix were purchased from Life technologies (California, USA). Oligos for qPCR were purchased from Integrated DNA Technologies, Inc. (Coralville, Iowa, USA). Agarose D-1 Low EEO-GQT was purchased from Conda Laboratories (Madrid, Spain).

Total RNA Extraction, cDNA Synthesis, and Real-Time qPCR Analysis. The Cells were treated with different classes of ARVs for 96 hours and total RNA was extracted and its concentration, purity and integrity ascertained as described previously (Adefolaju et al.). According to the manufacturer's instructions, genomic DNA was removed from total RNA using the DNase I, RNase-free kit. The DNAase I treated RNA was again cleaned with the GeneJET RNA Purification kit, re quantified and stored at $-80^{\circ} \mathrm{C}$ until used. According to the manufacturer's instructions, cDNA was synthesized using the MultiScribe ${ }^{\mathrm{TM}}$ Reverse Transcriptase from 700ng RNA. The reverse transcriptase reaction was carried out in a GeneAmp® PCR System 9600 Thermal Cycler for $10 \mathrm{~min}$ at $25^{\circ} \mathrm{C}, 120$ $\min$ at $37^{\circ} \mathrm{C}$ and then the enzyme was deactivated for $5 \mathrm{~min}$ at $85^{\circ} \mathrm{C}$. The cDNA aliquots were then utilized in $\mathrm{qPCR}$ reactions for VEGF165b, with TBP, RPLP0 and TFRC used as the endogenous reference genes. PCR reactions were amplified as described previously (Adefolaju et al.). PCR amplification was performed in a final volume of $20 \mathrm{ml}$ using the Power SYBR ${ }^{\circledR}$ Green PCR Master mix with the ABI 7500 real-time PCR machine. Primer sequences and PCR product sizes are shown in Table II. To confirm the absence of nonspecific amplification, PCR products were separated on 3 $\%$ agarose gels, stained with ethidium bromide and images acquired with the BioRad Gel Doc ${ }^{\circledR}$ XR (Model 170-8170 Segrate, Milan. Italy). Melt curves were generated for each PCR product using the Applied Biosystems ABI 7500 software. The relative mRNA expression levels of target genes in each sample were calculated using the qbasePLUS software (Biogazelle, Zulte, Belgium). The expression stability of the reference genes was evaluated using qbasePLUS version 2.3. This software uses a pair-wise comparison model to calculate the stability of each reference gene, and selects the two or more most stable genes from a panel of reference genes for normalisation (Hellemans et al., 2007). Genes are ranked based on a gene stability parameter $\mathrm{M}$, where a low $\mathrm{M}$ value

Table II Oligonucleotide sequences used for qPCR

\begin{tabular}{lll}
\hline Gene & Sequences $\left(\mathbf{5}^{\prime}\right.$-3' direction) & Product size (bp) \\
\hline VEGF165B & F: CGC AGA CGT GTA AAT GTT CCT G & 97 \\
& R: TTC CTG GTG AGA GAT CTG CAA G & \\
TBP & F: TGA TGC CTT ATG GCA CTG GAC TGA & 86 \\
& R: CTG CTG CCT TTG TTG CTC TTC CAA & \\
RPLP0 & F: TGC AGC TGA TCA AGA CTG GAG ACA & 178 \\
& R: TCC AGG AAG CGA GAA TGC AGA GTT & \\
TFRC & F: GGC ACC ATC AAG CTG CTG AAT GAA & 133 \\
& R: GTT GAT CAC GCC AGA CTT TGC TGA & \\
\hline
\end{tabular}


indicates high expression stability. To further indicate how stable a gene is expressed the qbasePLUS software also calculates a coefficient of variation $(\mathrm{CV})$. PCR base line $\mathrm{Cq}$ values were exported from the ABI 7500 software as an Excel file (Microsoft, Redmond, WA) and imported into the qbasePLUS software. The data was analysed with the default settings and the arithmetic mean of replicates was used. Data from standard curve experiments from the ABI 7500 software, imported into the qbasePLUS software, was used to generate amplification efficiencies and standard errors that are used downstream by the qbasePLUS software to determine normalised gene expression levels. The relative quantity of each target/ sample combination was scaled to the average $\mathrm{Cq}$ of corresponding target (scale set to untreated control in the qbasePLUS software). The relative expression of specific genes in the experiment were normalised as a ratio to the amount of the two most stably expressed reference genes according to the-CT method of Livak \& Schmittgen (2001).

Immunocytochemistry of VEGF165b. The effects of the antiretroviral drugs on VEGF165b localisation was determined by immuno-flourescence. The ABCAM@ double labelling procedure was followed for immunofluorescence analysis as previously described (Adefolaju et al.). Cells were incubated overnight with polyclonal rabbit anti-human VEGF165b (5 mg/ml) (ABCAM). The cells were then PBS washed and incubated for 2 hours with a Rhodamine-conjugated goat anti-rabbit antibody $(1: 1000 \mathrm{ABCAM})$ in the dark. Slides were rinsed, nuclei counterstained in 4',6-diamidino-2phenylindole, dihydrochloride (DAPI) $300 \mathrm{nM}$ for 5 mins, rinsed and mounted with fluoromount (Sigma). Negative control groups were set up to ensure that the secondary antibody was specific for the primary antibody. The primary antibody was substituted with $0.1 \%$ BSAIPBS and the normal protocol were carried out. In a second negative control, the cells were treated in the same way as the experimental slides, but the secondary antibodies were substituted with PBS. These controls were set up to ensure that crossreactivity was not taking place. Cells were visualized using a Zeiss Laser Scanning Confocal Microscope 780 under a Zeiss $100 \mathrm{X}$ oil immersion objective. For digital image analysis, ZEN 2010 software was used. The image acquisition settings remained constant for all exposures. Images were taken and using the ZEN 2010 (Carl Zeiss, Germany) image analysis software, the intensity of the fluorescence of each micrograph was analysed to determine whether there was any

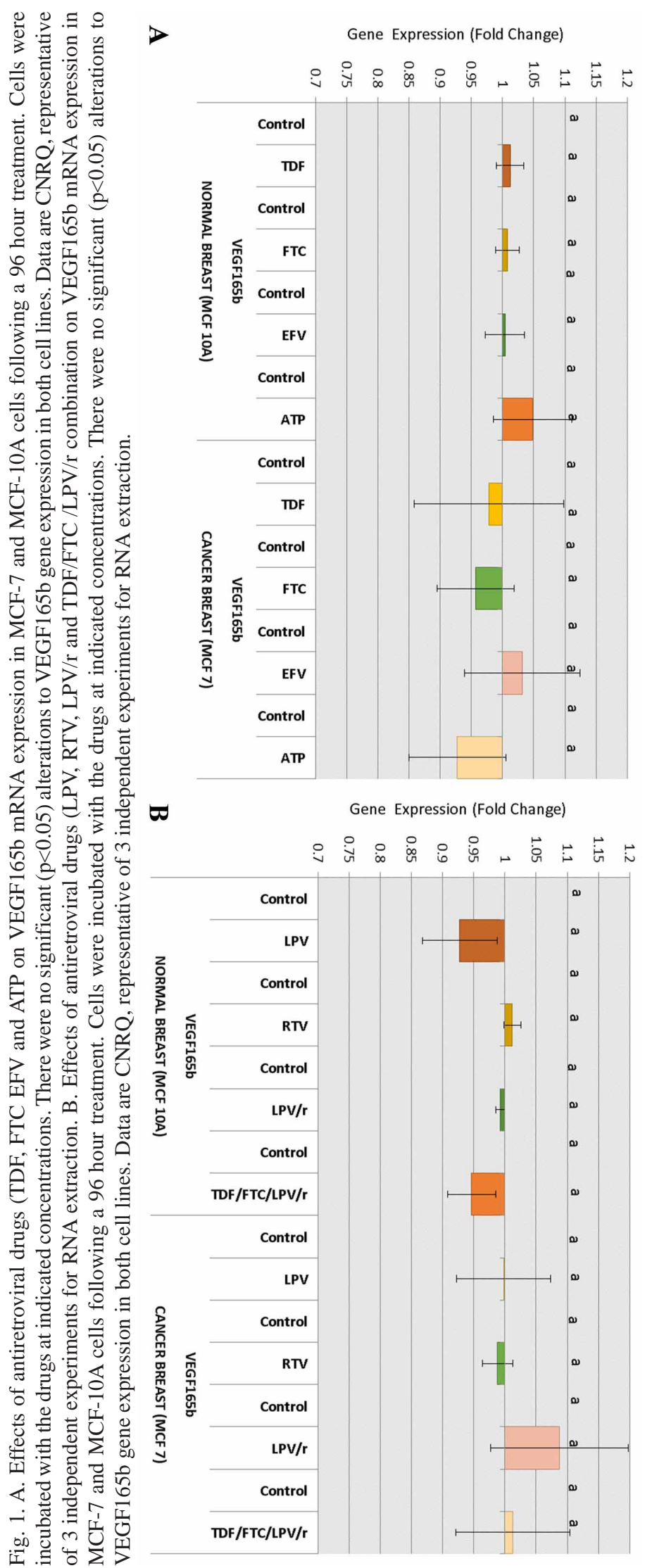


significant difference between the means of the different treatment groups, with regards to the expression of each protein within the regions of interest. Representative images are shown.

Statistical Analysis. To determine whether the expression of the genes of interest from the untreated differed significantly from those from the treated groups, the qbasePLUS software was used to conduct the analysis of variance (ANOVA), with significance level set at $p<0.05$. Immuno-fluorescent images were taken and using the ZEN 2010 (Carl Zeiss, Germany) image analysis software, the intensity of the fluorescence of each micrograph was analysed. This was done by using the software to initially define the regions of interest (ROIs); namely, the nucleus and cytoplasm. The mean intensity of each ROI from the treatment groups (according to Table I) were then analysed with the statistics software JMP ${ }^{\circledR}$ (Version 10.0 SAS Institute Inc., Cary, NC, USA). Data are reported as mean + standard deviation. After verifying the normal distribution and the homogeneity of the variance using an $F$ test $(p<0.05)$, a one-way analysis of variance (where a significance level of $p<$ 0.05 was set) was used to compare the results.

\section{RESULTS}

Effects of Antiretroviral drugs on the expression of antiangiogenic gene VEGF165b in MCF-7 and MCF-10A breast cell lines. The mRNA expression levels of the antiangiogenic VEGF splice variant VEGF165b was investigated after a 96 hour exposure to a variety of
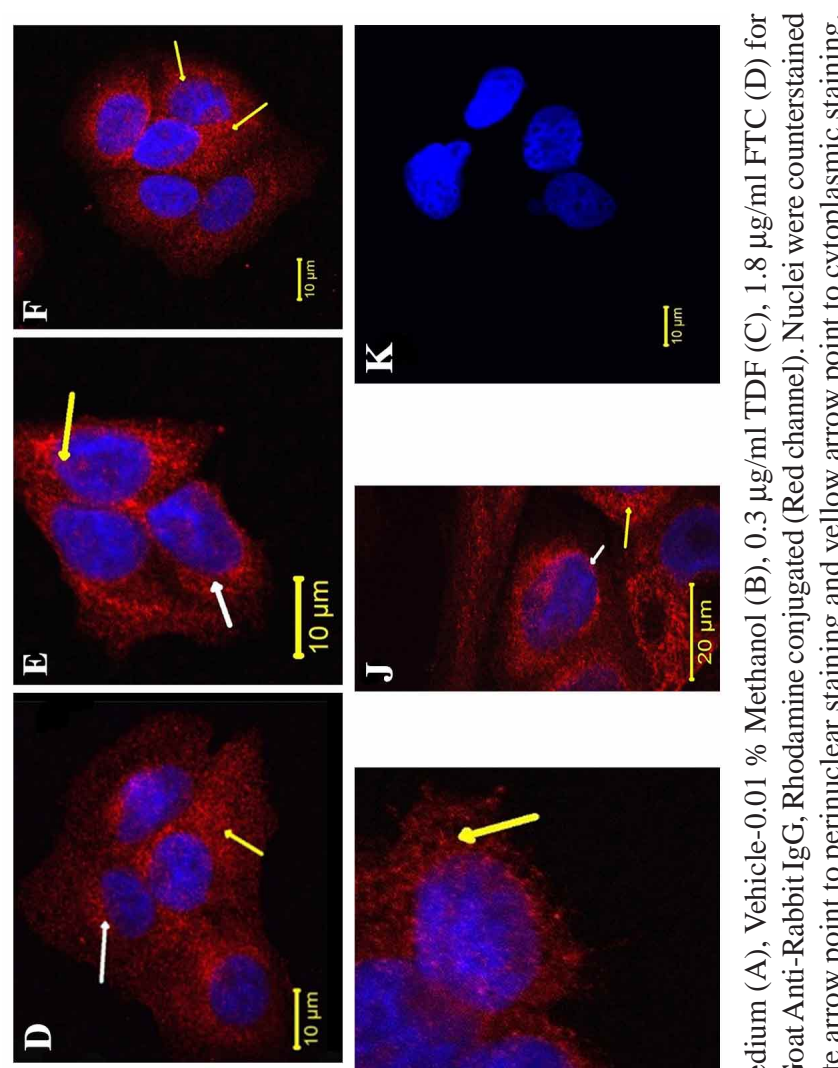

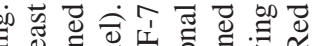

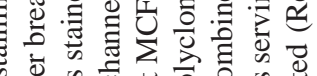

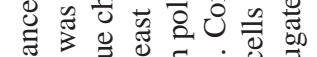

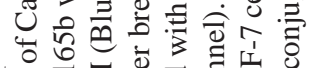

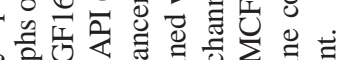

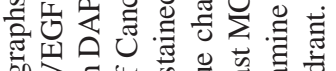

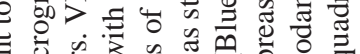

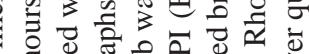
更 西

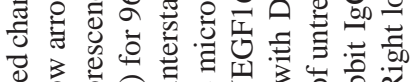

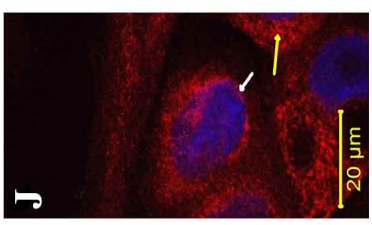
要
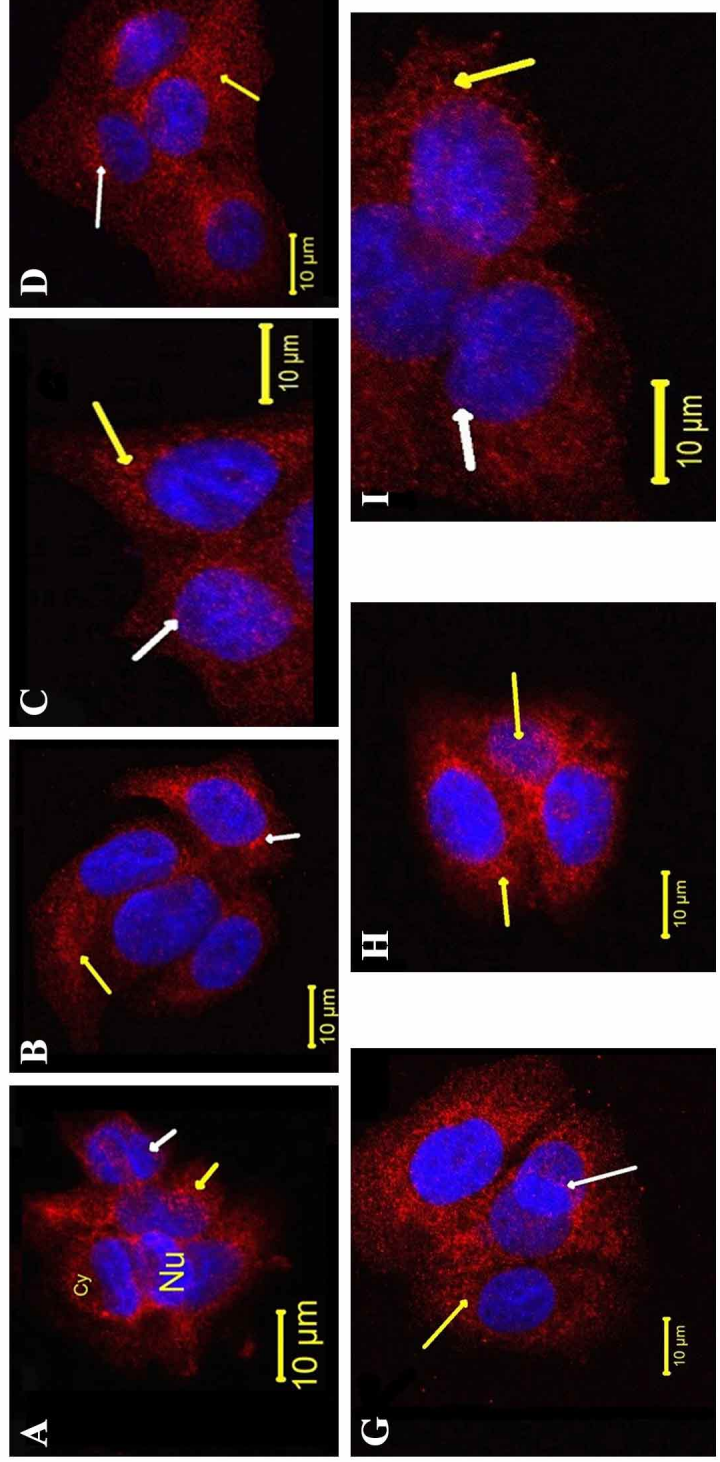

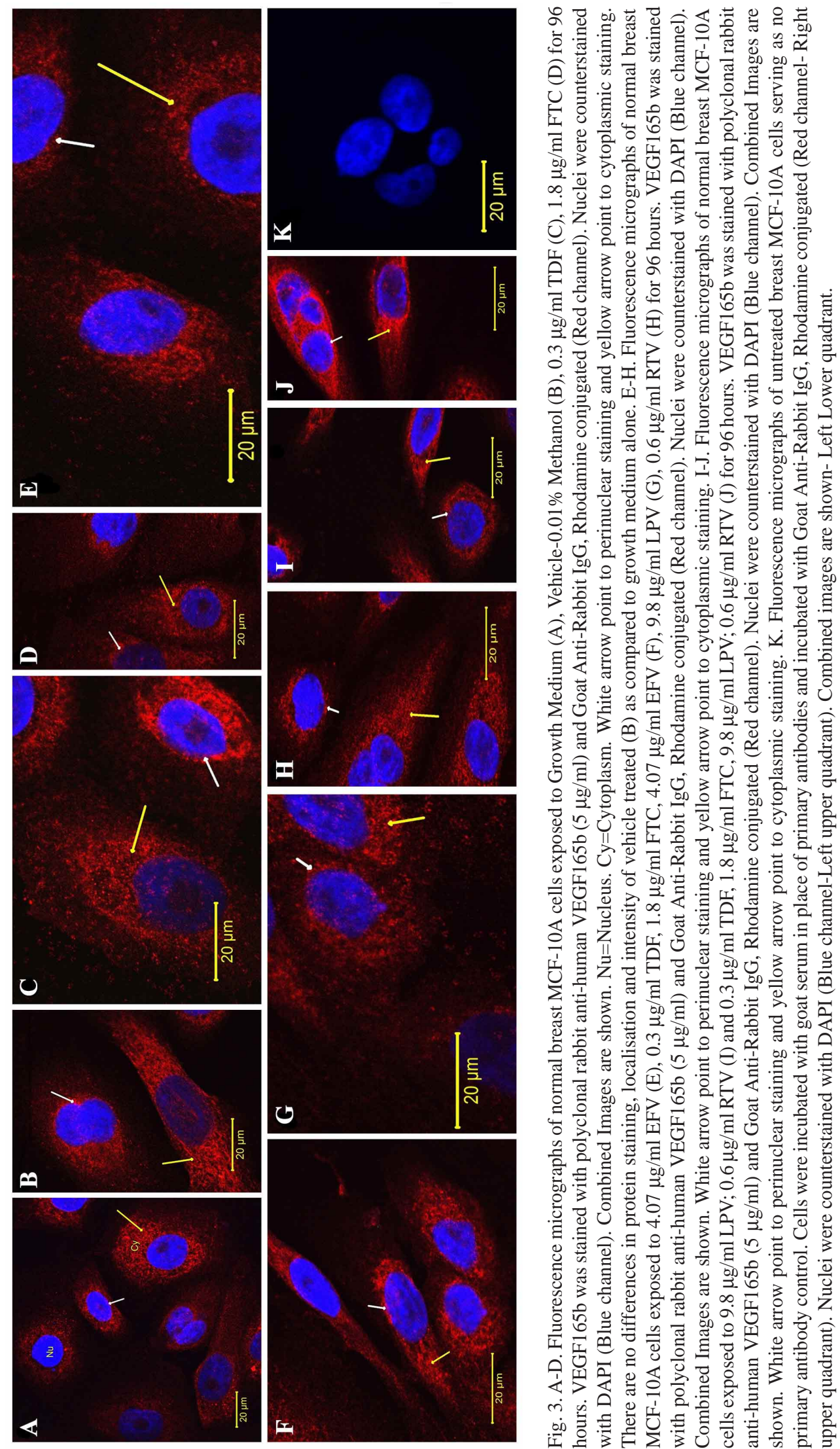

antiretroviral drugs (individually and in combination) in $\mathrm{MCF}-7$ and MCF-10A breast cell lines.

In response to TDF, VEGF165b was slightly up-regulated in the normal breast cells and downregulated in the breast cancer MCF-7 cells, (Fig. 1A). However, in both breast cell lines treated with TDF, the differences in fold changes were not significantly $(\mathrm{p}<0.05)$ different from the untreated controls.

After a 96 hour exposure to FTC, the levels of anti-angiogenic VEGF165 was just slightly down-regulated in the breast cancer MCF-7 cells (Fig. 1A). However, in both cell lines treated with FTC, the differences in fold changes in mRNA expression were not significantly $(p<0.05)$ different from the untreated controls. The nNRTI - EFV did not show any significant effects on VEGF165b mRNA expression in both cell lines but produced a slight upregulation of the gene in the MCF-7 cells. (Fig. 1A). In response to ATP, the levels of VEGF165b were slightly increased in the normal breast but decreased in the breast cancer cells (Fig. 1A). However, in both cell lines treated with ATP, the differences in fold changes were not significantly ( $\mathrm{p}<$ 0.05 ) different from the untreated controls. The 
protease inhibitors showed no significant $(\mathrm{p}<0.05)$ effects on the mRNA expression of VEGF165b in both breast cell lines (Fig. 1B). In response to LPV, VEGF165b levels were decreased in the normal breast cells only (Figure 1B), while in response to LPV/r, VEGF165b levels were increased in the breast cancer cell line, but again, the increase did not achieve statistical significance (Fig. 1B). The combinations of TDF/FTC/LPV/r also did not alter the levels of the angiogenesis related gene VEGF165b in both cell lines after a 96 hour exposure (Fig. 1B). Results were analysed with the qBASEPLUS software and normalised to the expression levels of TBP, TFRC and RPLP0.

Immunocytochemistry of antiangiogenic VEGF 165b protein in MCF-7 and MCF10-A cells exposed to antiretroviral drugs. The antiangiogenic VEGF165b protein is expressed and localised in the nuclei and cytoplasms of MCF-7 (Fig. 2A) and MCF-10A (Fig. 3A) cells. Exposing both breast cell lines to the different antiretroviral drugs individually and in combination for 96 hours showed no differences in the localisation of VEGF165b (Fig. 2B-J and Fig. 3B-J). Figs. 2B-J are representative images illustrating the effect of the antiretroviral drugs on expression of VEGF165b in MCF-7 cell cultures. Figures 3B- J are representative images illustrating the effect of the antiretroviral drugs on expression of VEGF165b in MCF$10 \mathrm{~A}$ cell cultures.

\section{DISCUSSION AND CONCLUSION}

This study investigated the possibility that the use of antiretroviral drugs could be a risk factor for the initiation or development of breast cancer in patients receiving cART. An analysis of the incidence of non-AIDS defining cancers in HIV-infected patients suggests that the incidence of NADM in these patients has significantly increased since the introduction and implementation of the combined antiretroviral therapy (Shiels et al., 2009), creating the need to effectively establish or rule out the possibility that candidate antiretroviral drugs may promote breast cancer. To promote cancer, we hypothesized that the antiretroviral drugs, either individually or in combination at the clinically relevant concentrations tested would down-regulate the antiangiogenic related splice variant VEGF165b mRNA and or protein, which are important factors regulating tumor angiogenesis. Testing the effects of different classes of antiretroviral drugs (individually and in combination), our findings show that the antiretroviral drugs; Tenofovir Disoproxil Fumarate, Emtricitabine, Efavirenz, Atripla, Lopinavir, Ritonavir, Kaletra and a combination of TDF/ FTC/LPV/r; all at clinically relevant concentrations (which reflect their steady-state peak plasma concentrations), do not alter the mRNA expression of the VEGF165b gene, neither do they alter the localization of their proteins in the human breast cancer cell line MCF-7 and non tumorigenic immortalised breast cell line MCF-10A.

Studies investigating the effects of antiretroviral drugs on the mRNA expression of the VEGF splice variant VEGF165b, in-vitro, in-vivo or even in other cell lines were not found in literature. In a glioblastoma cell line, HIV Protease Inhibitors - Nelfinavir and Amprenavir reduced the expression of vascular endothelial growth factor (VEGF) and hypoxia inducible factor-alpha (Pore et al., 2006). The same drugs however, did not produce any decrease in VEGF expression in immortalized human astrocytes.

Cancer development, invasion, and spread require that cancer cells possess the ability to proliferate and invade tissues when the extracellular matrix is compromised. Inflammatory and stromal cells entering tumours take part in these processes by producing paracrine factors, matrix metalloproteinases and other proteases that increase cancercell growth and extracellular-matrix degradation (Carmeliet \& Jain, 2000; Egeblad \& Werb, 2002). As a result, the invasion, spread and proliferation of cancer cells, together with extracellular matrix and basement membrane degradation are needed for angiogenesis and progression of tumours (Carmeliet \& Jain; Egeblad \& Werb). Protease inhibitors are considered to be strongly antiangiogenic compounds (Sgadari et al., 2002; 2003). Sgadari et al. (2002), demonstrated that PIs inhibited Kaposi sarcoma growth with the histological characteristics of treated mice showing that the regression of lesions was because the Protease Inhibitors restricted the formation of new blood vessels. Because Kaposi sarcoma is hastened by angiogenic factors secreted by Kaposi sarcoma cells in human or mice lesions, they examined the effects of Protease Inhibitors - Indinavir or Saquinavir on angiogenesis stimulated by subcutaneous injection of bFGF and VEGF in nude mice. Treatment with protease inhibitors was shown to block the formation of lesions and significantly reduce the amount of bFGF-induced angio-proliferative macroscopic lesions. Under microscopic examination, the sites of bFGF injection showed significantly reduced angiogenesis and spindle-cell growth in mice treated with protease inhibitors compared to control animals treated with saline. The PIs (at concentrations similar to those present in plasma from treated patients) were also found to block angiogenesis induced by both bFGF and VEGF individually in the chorioallantoic membrane-an established in vivo method for determining angiogenesis and evaluating the potency of anti-angiogenic agents. The Protease Inhibitors Indinavir and Saquinavir however were not shown to significantly affect bFGF-promoted multiplication, growth, 
and survival of endothelial cells derived from macrovasculature (Sgadari et al., 2002). Their data suggested that protease inhibitors effectively blocked tumour growth and tumour associated angiogenesis in xenograft tumour models, without creating extreme toxic effects. Protease Inhibitors however, are also considered to be anti-apoptotic (Adefolaju et al.; Rizza \& Badley, 2008) and therefore implicated in the development of cancer. In this study, the association demonstrated between PIs, NRTIs and NNRTIs and altered mRNA and protein expression of anti-angiogenic VEGF165b in the two breast cell lines were not statistically significant.

\section{ACKNOWLEDGEMENTS}

We thank Dr Clem Penny, Department of Internal Medicine, University of the Witwatersrand, Johannesburg, South Africa for providing the MCF-7 and MCF-10A Cells. This work was supported by the South African Medical Research Council.

ADEFOLAJU, G.A.; SCHOLTZ, K. E. \& HOSIE, M. J. Expresión de VEGF165b Antiangiogénico en Células MCF-7 y MCF10A de Mama Humana Expuesto a Inhibidores de la Transcriptasa Inversa y la Proteasa. Int. J. Morphol. 35(1):148-156, 2017.

RESUMEN: El tratamiento antirretroviral combinado (TARc), un régimen de combinación de múltiples fármacos, consistiendo generalmente en inhibidores nucleósidos de la transcriptasa reversa, inhibidores no-nucleósidos de la transcriptasa reversa e inhibodres de proteasa que alteran el patrón de mortalidad que afecta a infectados por el VIH incluyendo neoplasias definidas como no HIV (nADMs). La especulación es moneda corriente; TARc induce o promueve la progresión de nADMs como cáncer de mama? Por lo tanto, este estudio se diseñó para investigar los efectos de algunos de los fármacos antirretrovirales (en concentraciones clínicamente relevantes) sobre la expresión del gen anti-angiogénico; VEGF165b en dos líneas celulares de mama humana; MCF-7 y MCF-10A por PCR tiempo real e inmunofluorescencia. Todos los fármacos antirretrovirales y las combinaciones probadas pueden regular en forma ligera hacia arriba o hacia abajo la expresión de ARNm producidos por VEGF165b pero las alteraciones no fueron estadísticamente significativos. Además, no se alteran los niveles de proteína VEGF165b, para la localización en ambas líneas celulares. Los resultados aquí presentados sugieren que los medicamentos antirretrovirales probablemente no influyen en la vía angiogénica en el desarrollo del cáncer de mama en pacientes bajo el régimen antirretroviral combinado.

PALABRAS CLAVE: Inhibidor de la transcriptasa inversa; Inhibidores de la proteasa; VEGF165b; Cáncer de mama; MCF-7; MCF-10A.

\section{REFERENCES}

Achen, M. G.; Jeltsch, M.; Kukk, E.; Mäkinen, T.; Vitali, A.; Wilks, A. F.; Alitalo, K. \& Stacker, S. A. Vascular endothelial growth factor D (VEGFD) is a ligand for the tyrosine kinases VEGF receptor 2 (Flk1) and VEGF receptor 3 (Flt4). Proc. Natl. Acad. Sci. U. S. A., 95(2):548-53, 1998.

Adefolaju, G. A.; Theron, K. E. \& Hosie, M. J. Effects of HIV protease, nucleoside/non-nucleoside reverse transcriptase inhibitors on Bax, Bcl-2 and apoptosis in two cervical cell lines. Biomed. Pharmacother, 68(2):24151, 2014.

Bates, D. O.; Cui, T. G.; Doughty, J. M.; Winkler, M.; Sugiono, M.; Shields, J. D.; Peat, D.; Gillatt, D. \& Harper, S. J. VEGF165b, an inhibitory splice variant of vascular endothelial growth factor, is down-regulated in renal cell carcinoma. Cancer Res., 62(14):4123-31, 2002.

Blas-García, A.; Apostolova, N.; Ballesteros, D.; Monleón, D.; Morales, J. M.; Rocha, M.; Victor, V. M. \& Esplugues, J. V. Inhibition of mitochondrial function by efavirenz increases lipid content in hepatic cells. Hepatology, 52(1):115-25, 2010.

Carmeliet, P. VEGF gene therapy: stimulating angiogenesis or angiomagenesis? Nat. Med., 6(10):1102-3, 2000.

Carmeliet, P. \& Jain, R. K. Angiogenesis in cancer and other diseases. Nature, 407(6801):249-57, 2000

Egeblad, M. \& Werb, Z. New functions for the matrix metalloproteinases in cancer progression. Nat. Rev. Cancer., 2(3):161-74, 2002.

Engels, E. A.; Biggar, R. J.; Hall, H. I.; Cross, H.; Crutchfield, A.; Finch, J. L.; Grigg, R.; Hylton, T.; Pawlish, K. S.; McNeel, T. S. \& Goedert, J. J. Cancer risk in people infected with human immunodeficiency virus in the United States. Int. J. Cancer, 123(1):187-94, 2008.

Ferrara, N. Vascular endothelial growth factor: basic science and clinical progress. Endocr. Rev., 25(4):581-611, 2004.

Hellemans, J.; Mortier, G.; De Paepe, A.; Speleman, F. \& Vandesompele, J. qBase relative quantification framework and software for management and automated analysis of real-time quantitative PCR data. Genome Biol., 8(2):R19, 2007.

Hoeben, A.; Landuyt, B.; Highley, M. S.; Wildiers, H.; Van Oosterom, A. T. \& De Bruijn, E. A. Vascular endothelial growth factor and angiogenesis. Pharmacol. Rev., 56(4):549-80, 2004.

Houck, K. A.; Ferrara, N.; Winer, J.; Cachianes, G.; Li, B.; \& Leung, D. W. The vascular endothelial growth factor family: identification of a fourth molecular species and characterization of alternative splicing of RNA. Mol. Endocrinol., 5(12):1806-14, 1991.

Joukov, V.; Pajusola, K.; Kaipainen, A.; Chilov, D.; Lahtinen, I.; Kukk, E.; Saksela, O.; Kalkkinen, N. \& Alitalo, K. A novel vascular endothelial growth factor, VEGF-C, is a ligand for the Flt4 (VEGFR-3) and KDR (VEGFR-2) receptor tyrosine kinases. EMBO J., 15(2):290-8, 1996.

Livak, K. J. \& Schmittgen, T. D. Analysis of relative gene expression data using real-time quantitative PCR and the 2(-Delta Delta C(T)) Method. Methods, 25(4):402-8, 2001.

Manetti, M.; Guiducci, S.; Romano, E.; Ceccarelli, C.; Bellando-Randone, S.; Conforti, M. L.; Ibba-Manneschi, L. \& Matucci-Cerinic, M. Overexpression of VEGF165b, an inhibitory splice variant of vascular endothelial growth factor, leads to insufficient angiogenesis in patients with systemic sclerosis. Circ. Res., 109(3):e14-26, 2011.

Maqutu, D.; Zewotir, T.; North, D.; Naidoo, K. \& Grobler, A. Determinants of optimal adherence over time to antiretroviral therapy amongst HIV positive adults in South Africa: a longitudinal study. AIDS Behav., 15(7):1465-74, 2011.

Nachega, J. B.; Stein, D. M.; Lehman, D. A.; Hlatshwayo, D.; Mothopeng, R.; Chaisson, R. E. \& Karstaedt, A. S. Adherence to antiretroviral therapy in HIV-infected adults in Soweto, South Africa. AIDS Res. Hum. Retroviruses, 20(10):1053-6, 2004.

Nowak, D. G.; Woolard, J.; Amin, E. M.; Konopatskaya, O.; Saleem, M. A.; Churchill, A. J.; Ladomery, M. R.; Harper, S. J. \& Bates, D. O. Expression of pro- and anti-angiogenic isoforms of VEGF is differentially 
regulated by splicing and growth factors. J. Cell Sci., 121(Pt. 20):3487-95, 2008.

Olofsson, B.; Pajusola, K.; Kaipainen, A.; von Euler, G.; Joukov, V.; Saksela, O.; Orpana, A.; Pettersson, R. F.; Alitalo, K. \& Eriksson, U. Vascular endothelial growth factor B, a novel growth factor for endothelial cells. Proc. Natl. Acad. Sci. U. S. A., 93(6):2576-81, 1996.

Perrin, R. M.; Konopatskaya, O.; Qiu, Y.; Harper, S.; Bates, D. O. \& Churchill, A. J. Diabetic retinopathy is associated with a switch in splicing from anti- to pro-angiogenic isoforms of vascular endothelial growth factor. Diabetologia, 48(11):2422-7, 2005.

Pore, N.; Gupta, A. K.; Cerniglia, G. J. \& Maity, A. HIV protease inhibitors decrease VEGF/HIF-1alpha expression and angiogenesis in glioblastoma cells. Neoplasia, 8(11):889-95, 2006.

Powles, T.; Robinson, D.; Stebbing, J.; Shamash, J.; Nelson, M.; Gazzard, B.; Mandelia, S.; Møller, H. \& Bower, M. Highly active antiretroviral therapy and the incidence of non-AIDS-defining cancers in people with HIV infection. J. Clin. Oncol., 27(6):884-90, 2009.

Qiu, Y.; Hoareau-Aveilla, C.; Oltean, S.; Harper, S. J. \& Bates, D. O. The anti-angiogenic isoforms of VEGF in health and disease. Biochem. Soc. Trans., 37(Pt. 6):1207-13, 2009.

Rennel, E. S.; Harper, S. J. \& Bates, D. O. Therapeutic potential of manipulating VEGF splice isoforms in oncology. Future Oncol., 5(5):70312, 2009.

Rizza, S. A. \& Badley, A. D. HIV protease inhibitors impact on apoptosis. Med. Chem., 4(1):75-9, 2008

Sgadari, C.; Barillari, G.; Toschi, E.; Carlei, D.; Bacigalupo, I.; Baccarini, S.; Palladino, C.; Leone, P.; Bugarini, R.; Malavasi, L.; Cafaro, A.; Falchi, M.; Valdembri, D.; Rezza, G.; Bussolino, F.; Monini, P. \& Ensoli, B. HIV protease inhibitors are potent anti-angiogenic molecules and promote regression of Kaposi sarcoma. Nat. Med., 8(3):225-32, 2002.

Sgadari, C.; Monini, P.; Barillari, G. \& Ensoli, B. Use of HIV protease inhibitors to block Kaposi's sarcoma and tumour growth. Lancet Oncol., 4(9):537-47, 2003.

Shiels, M. S.; Cole, S. R.; Kirk, G. D. \& Poole, C. A meta-analysis of the incidence of non-AIDS cancers in HIV-infected individuals. J. Acquir. Immune Defic. Syndr., 52(5):611-22, 2009.

Sikora, M. J.; Rae, J. M.; Johnson, M. D. \& Desta, Z. Efavirenz directly modulates the oestrogen receptor and induces breast cancer cell growth. HIV Med., 11(9):603-7, 2010.

Silverberg, M. J. \& Abrams, D. I. AIDS-defining and non-AIDS-defining malignancies: cancer occurrence in the antiretroviral therapy era. Curr. Opin. Oncol., 19(5):446-51, 2007.

Torres, S. M.; Walker, D. M.; Carter, M. M.; Cook, D. L. Jr; McCash, C. L.; Cordova, E. M.; Olivero, O. A.; Poirier, M. C. \& Walker, V. E. Mutagenicity of zidovudine, lamivudine, and abacavir following in vitro exposure of human lymphoblastoid cells or in utero exposure of CD-1 mice to single agents or drug combinations. Environ. Mol. Mutagen., 48(3-4):22438, 2007.

Woolard, J.; Wang, W. Y.; Bevan, H. S.; Qiu, Y.; Morbidelli, L.; PritchardJones, R. O.; Cui, T. G.; Sugiono, M.; Waine, E.; Perrin, R.; Foster, R.; Digby-Bell, J.; Shields, J. D.; Whittles, C. E.; Mushens, R. E.; Gillatt, D. A.; Ziche, M.; Harper, S. J. \& Bates, D. O. VEGF165b, an inhibitory vascular endothelial growth factor splice variant: mechanism of action, in vivo effect on angiogenesis and endogenous protein expression. Cancer Res., 64(21):7822-35, 2004.

\author{
Corresponding author: \\ Adefolaju Gbenga Anthony \\ Department of Preclinical Sciences \\ School of Health Care Sciences \\ University of Limpopo \\ Private Bag $\times 1106$ \\ Sovenga 0727 \\ South Africa
}

\section{Email: gbenga.adefolaju@ul.ac.za}

Received: 09-09-2016

Accepted: 24-11-2016 